\title{
Gonadotropin releasing hormone analogue (GnRHa) alters the expression and activation of Smad in human endometrial epithelial and stromal cells Xiaoping $\mathrm{Luo}^{1}$, Jingxia $\mathrm{Xu}^{1,2}$ and Nasser Chegini*1
}

Address: ${ }^{1}$ Department of Obstetrics and Gynecology, University of Florida, Gainesville, Florida, USA and ${ }^{2}$ Present address: The Jackson Laboratory, Bar Harbor, Main, USA

Email: Xiaoping Luo - xiaoping@obgyn.ufl.edu; Jingxia Xu - jingxia@obgyn.ufl.edu; Nasser Chegini* - cheginin@obgyn.ufl.edu

* Corresponding author

Published: 16 December 2003

Reproductive Biology and Endocrinology 2003, I:125

This article is available from: http://www.rbej.com/content/I/I/I25

(c) 2003 Luo et al; licensee BioMed Central Ltd. This is an Open Access article: verbatim copying and redistribution of this article are permitted in all media for any purpose, provided this notice is preserved along with the article's original URL.
Received: 2I August 2003

Accepted: 16 December 2003

\begin{abstract}
Gonadotropin releasing hormone analogues $(\mathrm{GnRHa})$ are often used to regress endometriosis implants and prevent premature luteinizing hormone surges in women undergoing controlled ovarian stimulation. In addition to $\mathrm{GnRH}$ central action, the expression of $\mathrm{GnRH}$ and receptors in the endometrium implies an autocrine/paracrine role for $\mathrm{GnRH}$ and an additional site of action for $\mathrm{GnRHa}$. To further examine the direct action of $\mathrm{GnRH}$ (Leuprolide acetate) in the endometrium, we determined the effect of GnRH on endometrial stromal (ESC) and endometrial surface epithelial (HES) cells expression and activation of Smads (Smad3, -4 and -7), intracellular signals activated by transforming growth factor beta (TGF-beta), a key cytokine expressed in the endometrium. The results show that $\mathrm{GnRH}$ (0.I microM) increased the expression of inhibitory Smad7 mRNA in HES with a limited effect on ESC, while moderately increasing the common Smad4 and Smad7 protein levels in these cells $(P<0.05)$. GnRH in a dose- $(0.01$ to 10 microM) and time(5 to $30 \mathrm{~min}$ ) dependent manner decreased the rate of Smad3 activation (phospho-Smad3, $\mathrm{pSmad3)}$, and altered Smad3 cellular distribution in both cell types. Pretreatment with Antide ( $\mathrm{GnRH}$ antagonist) resulted in further suppression of Smad3 induced by $\mathrm{GnRH}$, with Antide inhibition of PSmad3 in ESC. Furthermore, co-treatment of the cells with GnRH + TGF-beta, or pretreatment with TGF-beta type II receptor antisense to block TGF-beta autocrine/paracrine action, in part inhibited TGF-beta activated Smad3. In conclusion, the results indicate that GnRH acts directly on the endometrial cells altering the expression and activation of Smads, a mechanism that could lead to interruption of TGF-beta receptor signaling mediated through this pathway in the endometrium.
\end{abstract}

\section{Introduction}

Excess production of ovarian steroids, as well as overexpression of their receptors, is believed to serve as an underlying molecular mechanism that promotes uterine abnormalities such as endometriosis, leiomyoma and endometrial cancer. Gonadotropin releasing hormone analogues (GnRHa) are often sought for medical manage- ment of these disorders, due to hypoestrogenic condition created by GnRHa therapy [1-3]. Short-term administration of GnRHa is also used to prevent premature luteinizing hormone (LH) surges in women undergoing controlled ovarian stimulation [4-8]. GnRHa therapy acts primary at the level of hypothalamus/pituitary/ovarian axis. However, accumulating evidence for the expression 
of $\mathrm{GnRH}$ and GnRH receptors in several peripheral tissues, including the uterus, implies an autocrine/paracrine action for $\mathrm{GnRH}$, and additional sites of action for GnRHa therapy [9-13]. GnRH treatment is reported to alter the rate of cell growth and apoptosis, and the expression of cell cycle proteins, growth factors, cytokines, proteases, and protease inhibitors in various cell types derived from peripheral tissues, including the uterus [9-21]. In addition, administration of GnRHa in women undergoing controlled ovarian stimulation is reported to induce an imbalance in endometrial expression of ovarian steroid receptors with a profound antimitotic effect, as compared to endometrium of the natural cycle [8], a condition that could result in an unfavorable environment for embryo implantation [4-7].

Transforming growth factor beta (TGF- $\beta$ ) is a key regulator of cell growth and differentiation, and the expression of extracellular matrix, adhesion molecules, proteases, and protease inhibitors [14,21-26]. TGF- $\beta$ and TGF- $\beta$ receptors are expressed in the endometrium, where their expression is regulated in part by ovarian steroids. Altered expression of TGF- $\beta$ has also been correlated with several disorders [27], and in the uterus this includes endometriosis, leiomyoma and endometrial cancer [28-32]. The uterine expression of TGF- $\beta$ and TGF- $\beta$ receptors is targeted by GnRH treatment, and GnRH is reported to inhibit ovarian steroid-induced TGF- $\beta$ expression in leiomyoma and myometrial smooth muscle cells, as well as matrix metalloproteinases and their inhibitors in endometrial stromal cells $[9,12,14,17,21]$.

Binding of TGF- $\beta$ to TGF- $\beta$ receptors results in the activation of multiple intracellular signaling pathways, including the Smad pathway [33]. Smad pathway, which specifically mediates TGF- $\beta$ receptors signaling from the cell surface to the nucleus, is comprised of pathway-specific regulatory Smad (RSmad 1, 2, 3, 5 and 8), the common-Smad (Smad4), and the inhibitory Smad (Smad6 and -7) [33]. Smad2 and Smad3 are phosphorylated by the activated TGF- $\beta$ type I receptor, associate with Smad4 and their complex translocates into the nucleus, where they direct specific transcriptional responses to TGF- $\beta$ actions. In contrast, the interaction of inhibitory Smads with TGF- $\beta$ type I receptors prevents phosphorylation of RSmads, resulting in interruption of TGF- $\beta$ receptor signaling [33]. We have recently reported the expression of Smad3, -4 and -7 in human endometrium, and demonstrated that their expression and Smad3 activation are regulated by TGF- $\beta$ in endometrial epithelial and stromal cells [34]. Recent studies have also demonstrated a functional interaction between GnRH and TGF- $\beta$ as well as activin, a member of TGF- $\beta$ family, involving Smad and MAPK pathways in the pituitary gonadotropes, resulting in regulation of GnRH and GnRH receptor expression [35-
38]. In the present study we sought to extend our previous work by examining the direct action of GnRH on Smad expression and activation, as well as GnRH functional interaction with TGF- $\beta$ action in isolated endometrial stromal cells and endometrial surface epithelial cell (HES).

\section{Materials and Methods}

All the materials for isolation and culturing of endometrial cells, RT-PCR, Western blotting and immunocytochemistry were purchased from commercial sources as described [34,39]. Portions of endometrial tissue were collected from premenopausal women $(\mathrm{N}=3)$ who were undergoing hysterectomy for symptomatic uterine leiomyomas. These patients were not taking any hormonal medications at least during the 3 months prior to surgery. The tissues were collected at the University of Florida affiliated Shands Hospital with the approval of the Institutional Review Board.

The endometrial tissues were used for isolation of endometrial stromal cells (ESC) as previously described [34]. Human endometrial surface epithelial cell line (HES) was kindly provided by Dr. Douglas Kniss (Ohio State University, Columbus Ohio). The isolated ESC and HES were cultured as previously described [34]. To determine the direct action of GnRH (Leuprolide acetate; LA) on Smads mRNA and protein expression, ESC and HES were cultured at $1 \times 10^{6} \mathrm{cell} /$ well in 6 well dishes in media containing 10\% FBS for 48 hrs. The cells were washed and incubated in serum free/phenol red-free media for an additional $24 \mathrm{hrs}$ and then treated with GnRH $(0.1 \mu \mathrm{M})$ for 2, 4, 6 and $12 \mathrm{hrs}$ to determine Smad mRNA expression, and 18, 24 and 36 hrs to determine Smads protein production. Total RNA was isolated using Trizol (Invitrogen, Carlsbad, CA), and an equal amount of RNA ( $2 \mu \mathrm{g})$ was used to co-amplify Smads and glyceraldeyde-3 phosphate dehydrogenase (G3PDH) mRNA by RT-PCR as previously described [39]. Optimal amplification condition within the logarithmic phase was established over a range of 25-35 cycles with primers for Smads and G3PDH used at equal concentrations with identical PCR buffer containing $1.5 \mathrm{mM} \mathrm{MgCl}_{2}$. The PCR temperature profile consist of cycle denaturation $\left(95^{\circ} \mathrm{C}\right.$ for $\left.1 \mathrm{~min}\right)$, annealing (55$61^{\circ} \mathrm{C}$ for $\left.30 \mathrm{~s}\right)$, and extension $\left(72^{\circ} \mathrm{C}\right.$ for $\left.1 \mathrm{~min}\right)$ followed by an additional $5 \mathrm{~min}$ extension at $72^{\circ} \mathrm{C}$ in the presence of Taq polymerase added at the first annealing incubation. Controls included omission of the reverse-transcription step before PCR amplification, co-amplification of G3PDH mRNA, and inclusion of water blanks. After a 3035 cycle of amplification the co-amplified Smad:G3PDH PCR products were separated on $1 \%$ agarose gels. The relative level of Smads mRNA expression was determined from the band intensities and reported as fold changes in Smad:G3PDH mRNA ratio. For protein analysis, the cells 
were directly lysed in a buffer containing $50 \mathrm{mM}$ Hepes (pH 7.4), 1\% Nonidet P-40, 0.5\% deoxycholate, $5 \mathrm{mM}$ EDTA, $1 \mathrm{mM}$ sodium Ortho-vanadate, $5 \mathrm{mM} \mathrm{NaF}$ and phosphatase and protease inhibitor cocktails (Sigma Chemical, St Louis, MO). The cell lysates were centrifuged at $14,000 \times \mathrm{g}$ for $15 \mathrm{~min}$ at $4^{\circ} \mathrm{C}$ the supernatants were collected and following determination of their total protein content (Pierce, Rockford, IL), an equal amount of sample proteins were subjected to immunoblot analysis [34,39]. The level of Smad protein production was determined from the band intensity visualized using enhanced chemiluminescence reagents [34,39].

To determine the dose- and time-dependent effect of GnRH on Smad activation (phosphorylated Smad3, pSmad3), HES and ESC were cultured under serum-free/ phenol red-free conditions and then treated with 0.01 to $10 \mu \mathrm{M}$ of $\mathrm{GnRH}$ for $15 \mathrm{~min}$, or with $0.1 \mu \mathrm{M}$ of $\mathrm{GnRH}$ for 5,15 and $30 \mathrm{~min}$. Total protein was isolated and subjected to immunoblotting using anti pSmad $2 / 3$ and Smad 3 antibodies, determining the level of Smad3 activation in these cells. To determine the effect of GnRH on translocation of activated Smad3 into the nucleus, HES and ESC were cultured in eight-well slides (Nalge Nunc, Naperville, IL) for $24 \mathrm{hrs}$ in a medium containing 10\% serum, and $24 \mathrm{hrs}$ under a serum-free/phenol red-free condition; washed and treated with $\mathrm{GnRH}(0.1 \mu \mathrm{M})$ for 5,15 and $30 \mathrm{~min}$. The cells were washed in phosphate-buffered saline (PBS), fixed in methanol and immunostained with Smad3 antibodies by fluorescein isothiocyanate (FITC)-labeled-indirect method [34,40]. After incubation, the cells were washed with PBS and Vectashield with DAPI (Vector Laboratories) as the mounting medium. Images were captured using an Olympus IX70 microscope configured with DAPI and FITC fluorescent excitation filters, and equipped with digital camera and software image analysis package (Olympus Inc., Melville, NY).

To determine the effect of GnRH on TGF- $\beta$-induced Smad3 activation, HES and ESC were cultured under serum-free/phenol red-free condition and the treated with GnRH $(0.1 \mu \mathrm{M})$, TGF- $\beta 1(2.5 \mathrm{ng} / \mathrm{ml})$ or GnRH + TGF- $\beta 1$ for $15 \mathrm{~min}$. The specificity of GnRH action on Smad3 activation was determined in serum-starved HES and ESC pretreated with GnRH antagonist, Antide $(10 \mu \mathrm{M})$ for 2 hrs prior to exposure to GnRH $(0.1 \mu \mathrm{M})$ for $15 \mathrm{~min}$. To determine if the autocrine/paracrine action of TGF- $\beta$ is in part responsible for activation of Smad3, HES and ESC were treated with TGF- $\beta$ receptor type II antisense in order to block the autocrine/paracrine action of TGF- $\beta$. HES and ESC were treated with $1 \mu \mathrm{M}$ of TGF- $\beta$ type II receptor antisense or sense 20 mer oligonucleotides for 24 hrs [21,39], washed with PBS and then treated with GnRH $(0.1 \mu \mathrm{M})$ for 5, 15 and $30 \mathrm{~min}$. Following treatments total protein was isolated and subjected to immunoblotting to deter- mine the level of Smad3 activation in parallel with total Smad 3 and $\beta$ actin (control) as described [34,39,40].

The data is presented as mean \pm SEM of three independent experiments. Experiments involving ESC the cells were prepared from three different tissues. The data was analyzed using unpaired Student t-test and repeated measure analysis of variance (ANOVA). A probability level of $\mathrm{P}<$ 0.05 was considered significant.

\section{Results}

To evaluate the effect of GnRH on Smad expression, endometrial surface epithelial (HES) and endometrial stromal cells (ESC) were maintained under serum-free conditions and then treated with $\mathrm{GnRH}(0.1 \mu \mathrm{M})$ for 2, 4, 6 and 12 hrs to determine Smad mRNA expression, or for 18,24 and 36 hrs to determine Smad protein production. As shown in Figure 1, GnRH had little or no significant effect on the expression of Smad3 and Smad4 mRNA in HES and ESC (Bar graphs are not shown), while it significantly increased the expression of Smad7 in HES $(\mathrm{P}<$ 0.05 ) with a limited effect on ESC. At the protein level, GnRH inhibited Smad3 production in ESC and HES after 18 and 36 hrs respectively, which increased in ESC after 36 hrs $(P<0.05$, Fig. 2). However, GnRH treatment increased the production of Smad4 and Smad7 protein in ESC after 18 to 24 hrs; while in HES GnRH action occurred after 36 hrs of treatment with an inhibitory effect on Smad7 at 18 hrs $(\mathrm{P}<0.05$; Fig. 2$)$. The results indicate that $\mathrm{GnRH}$, in a time- and cell specific-manner, differentially regulates the expression of Smads in endometrial epithelial and stromal cells.

We then determine whether GnRH alters the activation of Smad3, either alone, or Smad3-induced by TGF- $\beta$. Treatment of serum-starved HES and ESC with GnRH resulted in suppression of Smad3 activation (pSmad3) a time (Fig. 3A) and dose (Fig. 3B) dependent manner in both cells (P $<0.05)$. Smad3 was primarily immunolocalized in cytoplasmic compartment of HES and ESC, and GnRH (0.1 $\mu \mathrm{M}$ ) treatment for 5, 15 and 30 min resulted in accumulation of Smad3 around the nuclear periphery, with limited translocation into the nucleus (Fig. 4; show representative after 15 min of treatment). To determine the specificity of GnRH action on Smad3 activation, the cells were pretreated with GnRH antagonist, Antide $(10 \mu \mathrm{M})$, for 2 hrs prior to treatment with GnRH $(0.1 \mu \mathrm{M})$. Treatment with Antide inhibited Smad3 activation in ESC, with further inhibition following co-treatment with Antide + GnRH compared to GnRH in both cell types ( $\mathrm{P}<0.05$; Fig. 5). The results suggest that both GnRHa (GnRH and Antide) alter Smad activation in endometrial epithelial and stromal cells, however, whether GnRHa directly utilize Smad pathway or their actions are mediated through crosstalk with components of other pathways activated by GnRH 

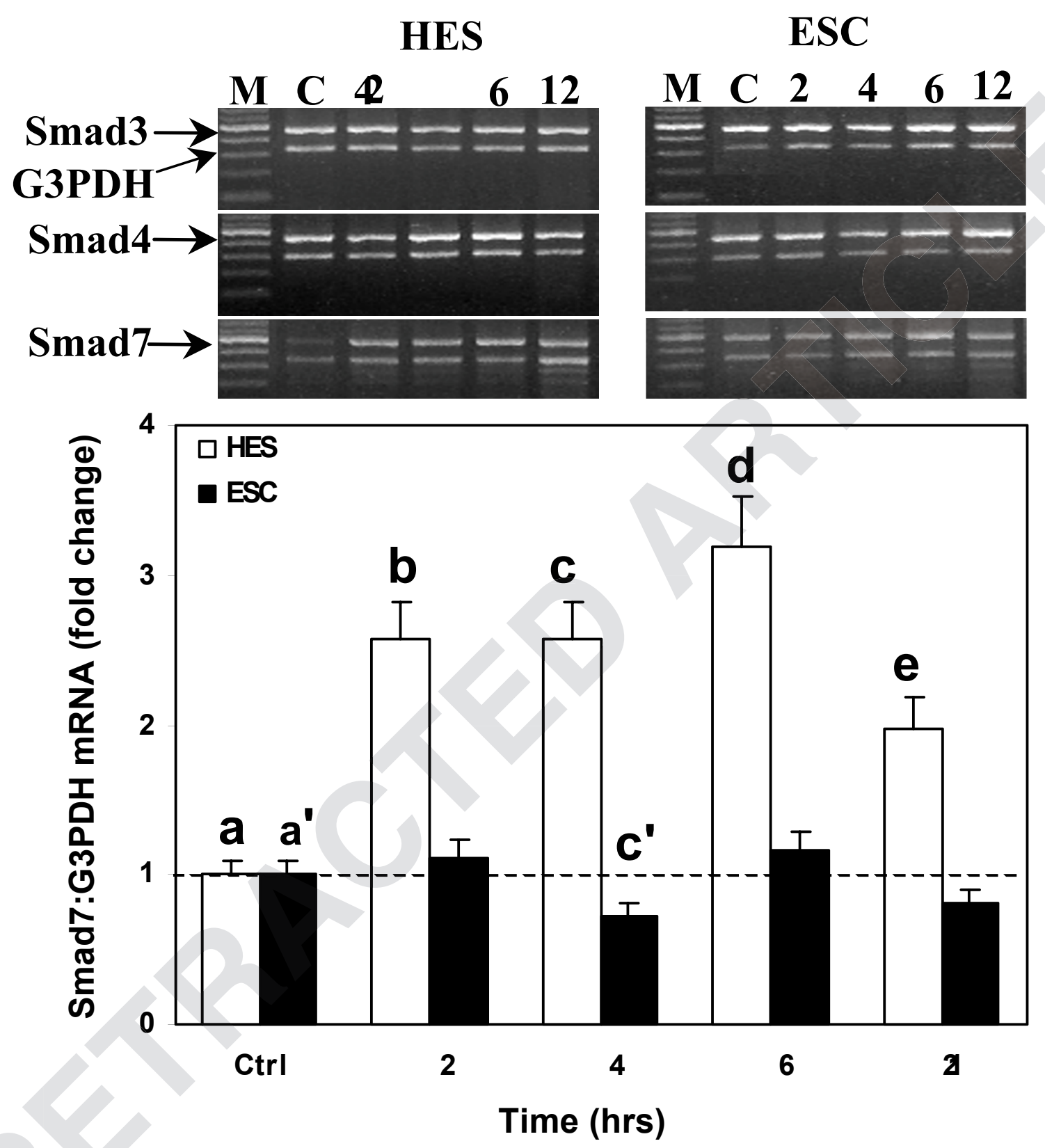

Figure I

Time dependent action of GnRH (leuprolide acetate) on Smad3, Smad4 and Smad7 (arrows) mRNA expression in human endometrial surface epithelial cells (HES) and isolated endometrial stromal cells (ESC). Serum-starved cells were treated with $\mathrm{GnRH}(0 . \mathrm{l} \mu \mathrm{M})$ for 2 to $12 \mathrm{hrs}$ and total RNA was isolated from treated and untreated control (Ctrl) cells and subjected to semi-quantitative RT-PCR co-amplifying Smads and G3PDH (lower bands) mRNA shown from a representative experiment. The bar graph show the mean \pm SEM of fold change of ratio of Smad7:G3PDH mRNA expression from three independent experiments. b, $c, d$, and e and $c^{\prime}$ and are significantly different from a and a', respectively $(p<0.05)$. M = DNA marker. 


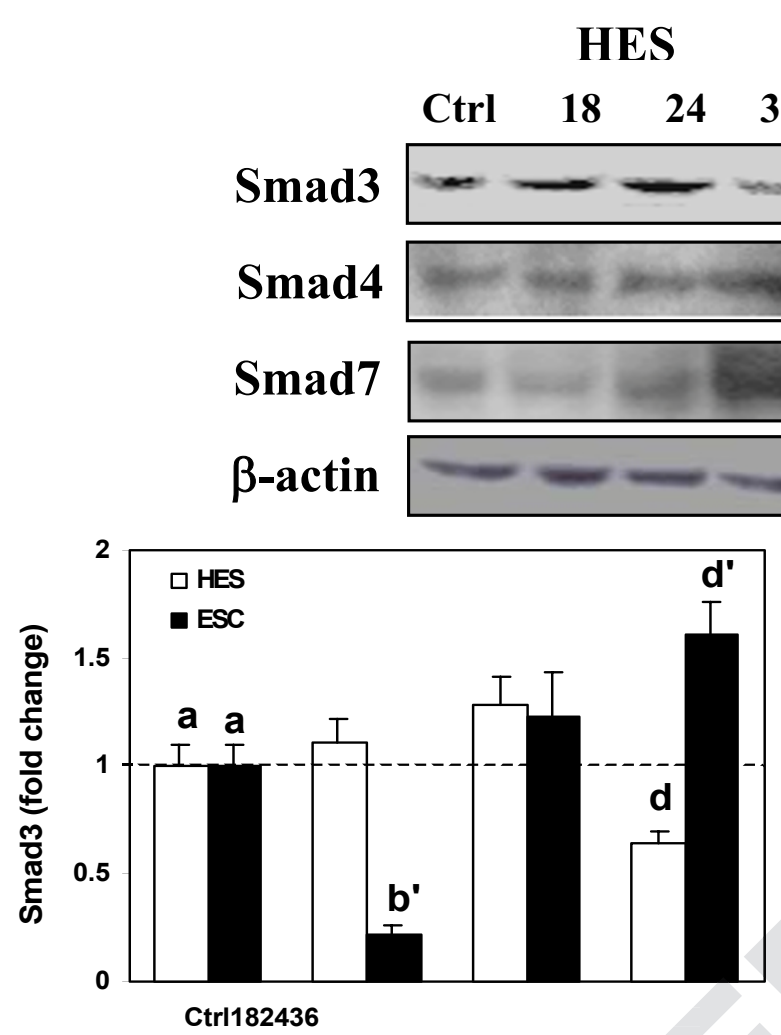

Time (hrs)

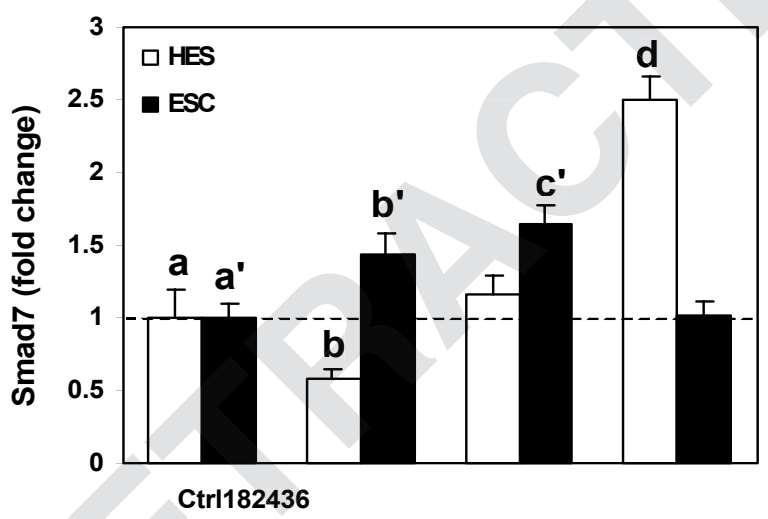

Time (hrs)

\section{ESC}
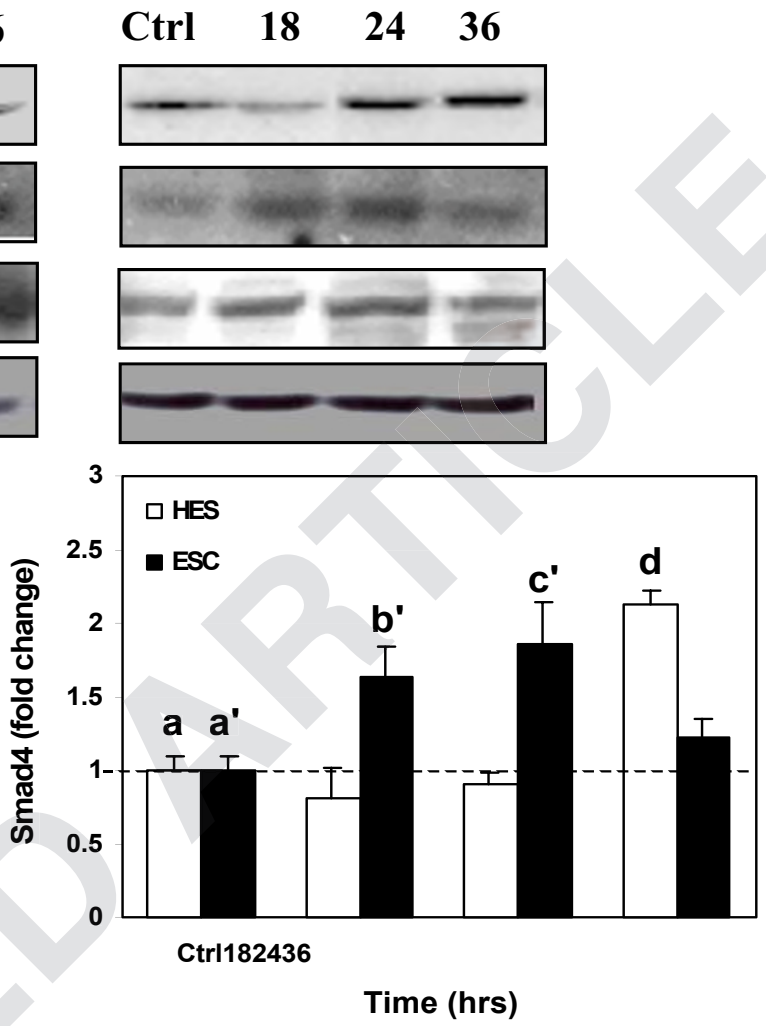

\section{Figure 2}

Time dependent action of GnRH (leuprolide acetate) on Smad3, Smad4 and Smad7 protein expression in HES and ESC. Serumstarved cells were treated with $\mathrm{GnRH}(0.1 \mu \mathrm{M})$ for 18, 24 and $36 \mathrm{hrs}$ and cell lysates were prepared from treated and untreated control (Ctrl) and analyzed by immunoblotting for Smads and $\beta$-actin as loading control, all shown from a representative experiment. Bar graphs show the mean \pm SEM of fold change in Smads expression from three independent experiments. The denote d, b' and d' (Smad3), d, b', and c' (Smad4) and b, d, b' and c' (Smad7) are significantly different from a and a', respectively $(p<0.05)$. 

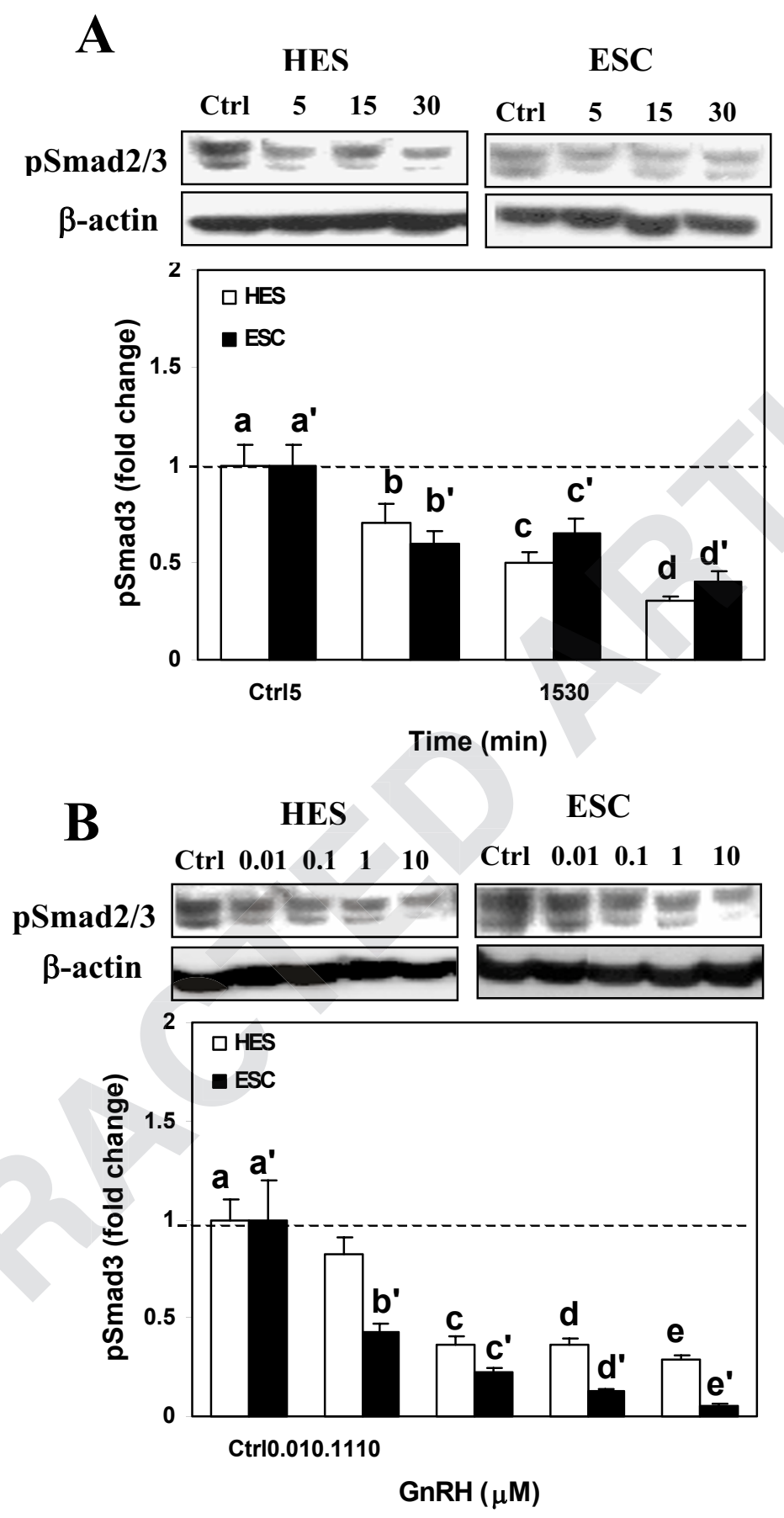

\section{Figure 3}

Time- (A) and dose- (B) dependent effects of GnRH (Leuprolide acetate) on the rate of Smad3 activation (phospho-Smad3; PSmad3). HES and ESC were incubated under serum-free condition and treated with GnRH (0.I $\mu \mathrm{M})$ for 5 , I5 and 30 min, or with $\mathrm{GnRH}$ at 0.01 to $10 \mu \mathrm{M}$ for $15 \mathrm{~min}$. The cell lysates were prepared and analyzed by immunoblotting for $\mathrm{pSmad} 2 / 3$ and $\beta$ actin as loading control, shown from a representative experiment. Bar graphs show the mean \pm SEM of fold change in the rate of Smad3 activation from three independent experiments. In Fig. A: denotes b, c, d, b', c', and d' and in Fig. B, c, d, e, b', c', d,' and e'are significantly different from a and a', respectively $(p<0.05)$. 

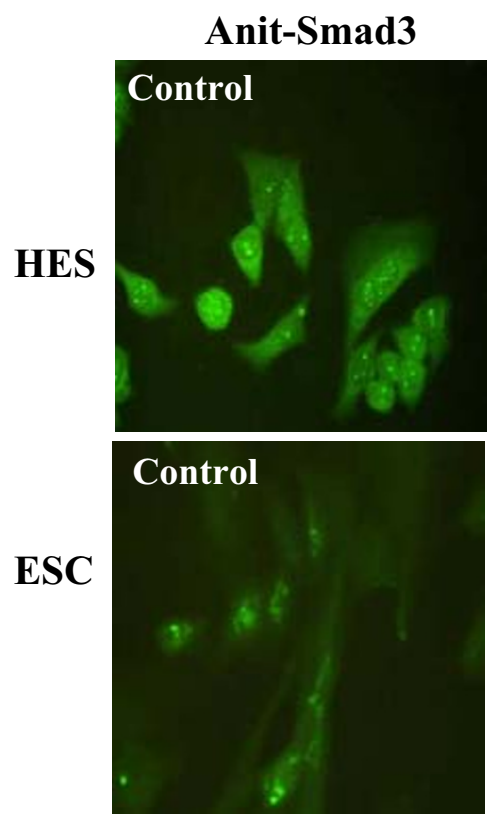

DAPI
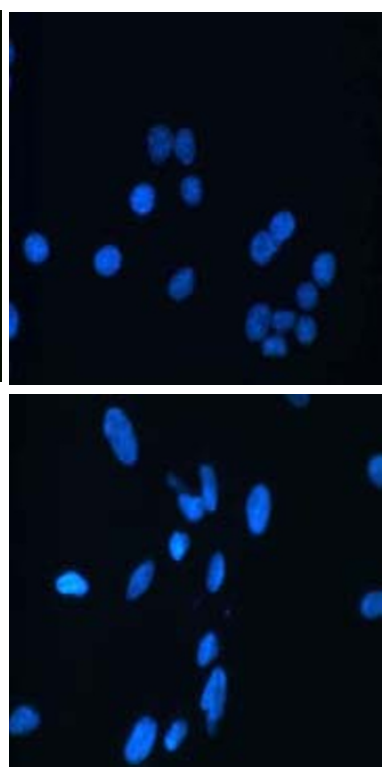

Anit-Smad3
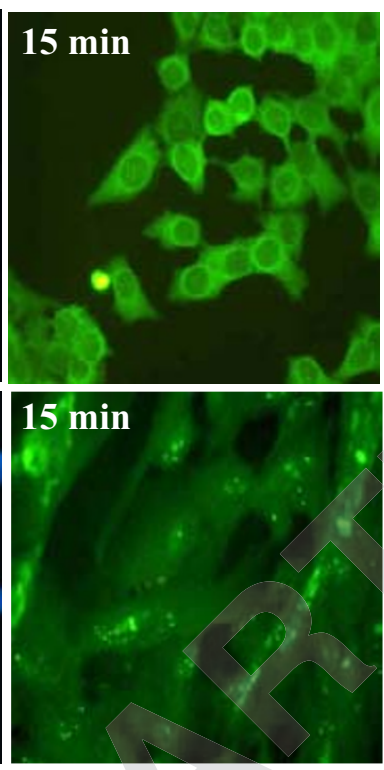

DAPI
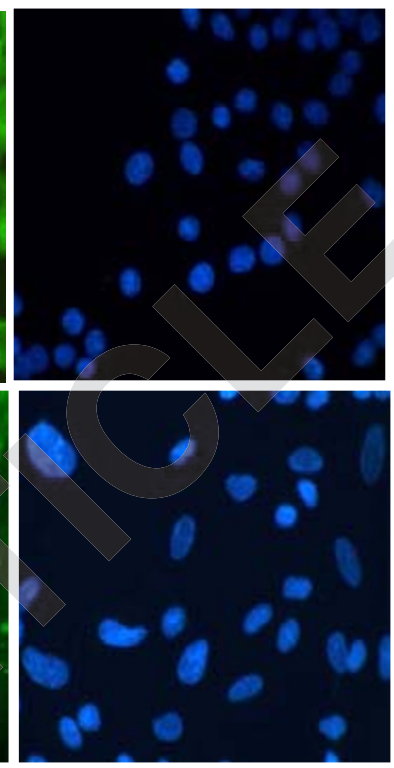

\section{Figure 4}

Immunofluorescence localization of Smad3 in HES and ESC. The cells were incubated under serum-free condition for 24 hrs then treated with $\mathrm{GnRH}(0.1 \mu \mathrm{M})$ for 5,15 and $30 \mathrm{~min}$. Note subcellular localization of Smad3 in untreated control with mostly cytoplasmic and limited nuclear localization, while GnRH-treatment resulted in more cytoplasmic accumulation of Smad3. The figures are shown after 15 min of GnRH treatment with FITC staining used to localize Smad3 and DAPI staining for the nuclei.

receptors remains to be investigated. Co-treatment of serum-starved HES and ESC with GnRH + TGF- $\beta$ also resulted in inhibition of Smad3 activation compared to TGF- $\beta$ treated cells $(P<0.05$; Fig. 6$)$. The autocrine/paracrine action of TGF- $\beta$ in part account for Smad3 activation since pretreatment of HES and ESC with TGF- $\beta$ type II receptor antisense prior to exposure to GnRH resulted in further suppression of Smad3 activation compared to sense-treated cells (Fig. 7).

\section{Discussion}

In the present study we demonstrated that GnRH, in a dose, time, and cell specific manner, alters the endometrial epithelial and stromal cells expression and production of Smad3, -4 and -7 , intracellular proteins that mediate TGF- $\beta$ receptor signaling from the cell surface to the nucleus. These actions of GnRH on Smads mRNA expression were limited to Smad7, while it induced both stimulatory and inhibitory effects on their protein production. More specifically, GnRH inhibited Smad3 production in ESC and HES, with an increased production in ESC following longer exposure. GnRH increased the production of Smad4 and Smad7 in ESC, however in HES
GnRH action occurred after 36 hrs, with an inhibition of Smad7 after 18 hrs of treatment. Although the molecular mechanism how GnRH alters the expression of Smads is not known and requires detailed investigation, their differential regulation at protein levels suggests possible posttranscriptional regulation. The action of GnRH on Smad expression could occur indirectly through the inhibition of TGF- $\beta$ and TGF- $\beta$ receptors expression, since TGF- $\beta$ regulates its own expression and the expression of Smads in several cell types [44-47]. In this respect we have previously reported that GnRH alters the expression of TGF- $\beta$, TGF- $\beta$ receptors and Smads in leiomyoma and myometrial smooth muscle cells, and TGF- $\beta$ self-regulation in endometrial stromal cells $[9,21,39]$. Alternatively, GnRH-induced hypoestrogenic condition could result in alteration of Smads expression, because ovarian steroids regulate the endometrial expression of TGF- $\beta$ and TGF- $\beta$ receptors [48-50]. A recent report indicated that direct binding of AP-1 (fos/jun) proteins to a Smad binding element facilitates GnRH- and activin-mediated transcriptional activation of the GnRH receptor gene [37]. 


\section{HES}

pSmad2/3

$\beta$-actin

GnRH Antide
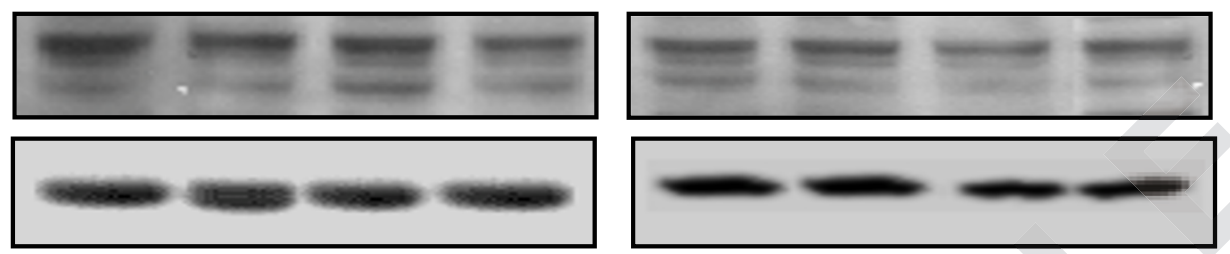

ESC

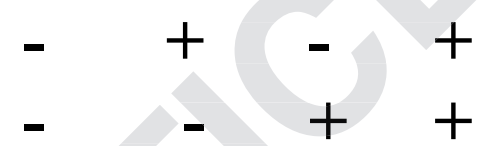

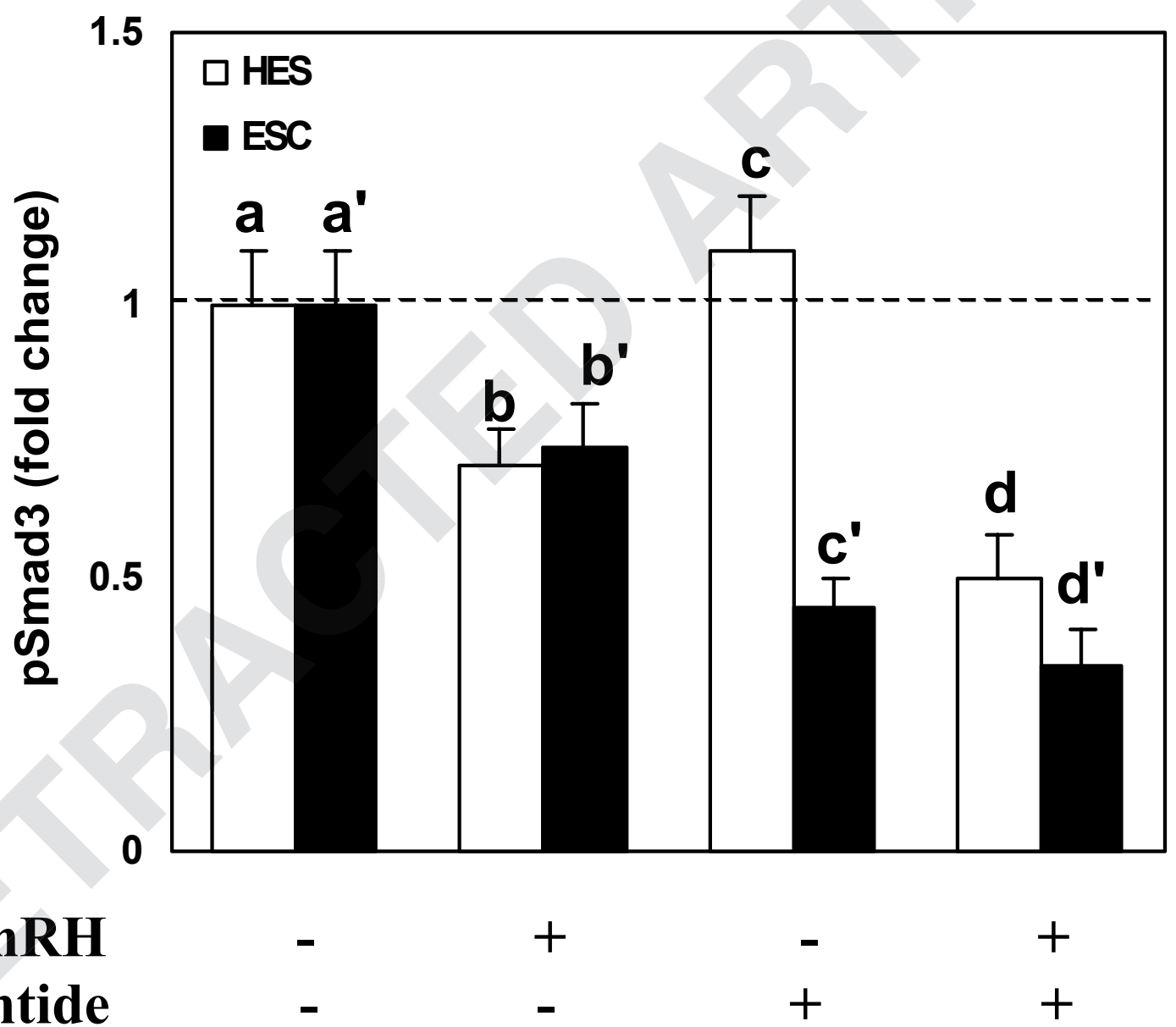

Figure 5

The effect of GnRH (0.I $\mu \mathrm{M})$ and GnRH antagonist (Antide, $10 \mu \mathrm{M}$ ) on Smad3 activation in HES and ESC. Serum-starved cells were treated with Antide for 2 hrs prior to treatment with GnRH for 15 min. The cells lysates were prepared from treated and untreated control (-) and analyzed by immunoblotting for $\mathrm{pSmad} 2 / 3$ and $\beta$-actin as loading control, shown from a representative experiment. Bar graph shows the mean \pm SEM of fold change in the rate of Smad3 activation from three independent experiments with denotes $b, c, d, b^{\prime}, c^{\prime}$ and d'are significantly different from a and a,' respectively $(p<0.05)$. 


\section{HES}

pSmad2/3

\section{$\beta$-actin}

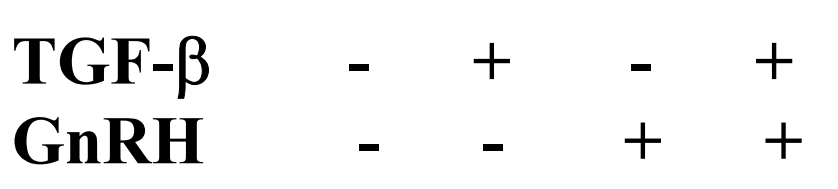

\section{ESC}
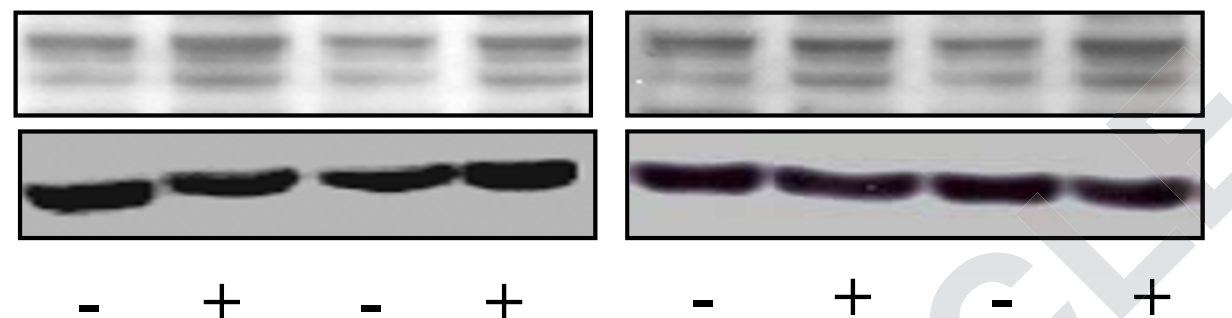

$+$

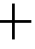

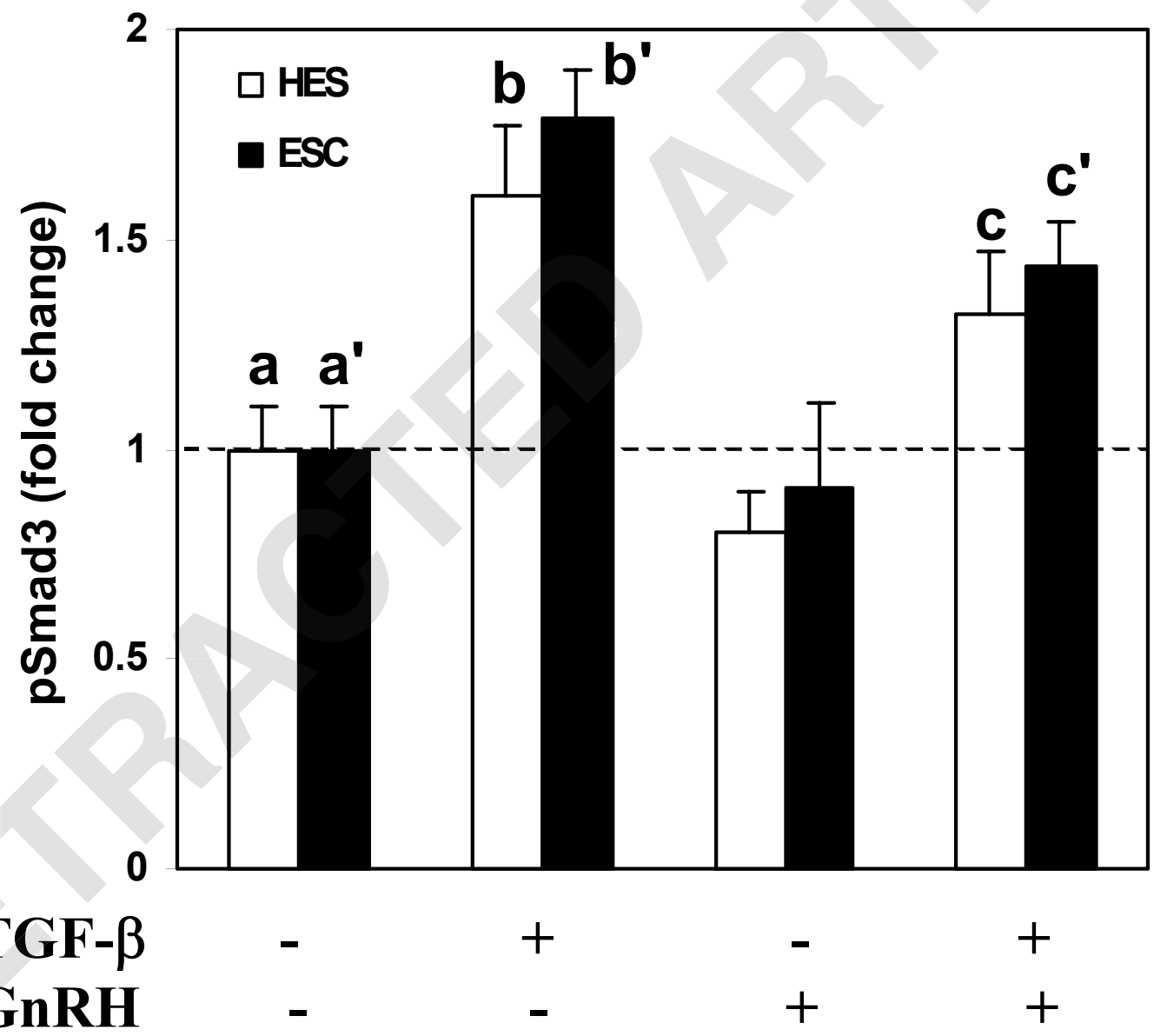

Figure 6

The effect of GnRH on TGF- $\beta$ I-induced Smad3 activation in HES and ESC. Serum-starved HES and ESC were co-treated with TGF- $\beta$ I $(2.5 \mathrm{ng} / \mathrm{ml})$ and $\mathrm{GnRH}(0.1 \mu \mathrm{M})$ for $15 \mathrm{~min}$ and cell lysates from treated $(+)$ and untreated $(-)$ groups were analyzed by immunoblotting for $\mathrm{pS}$ Smad2/3 and $\beta$-actin as loading control, shown from a representative experiment. Bar graph shows the mean \pm SEM of fold change in the rate of Smad3 activation from three independent experiments with denotes $b, c, b^{\prime}$ and $c^{\prime}$ are significantly different from a and a', respectively $(\mathrm{p}<0.05)$. 
HES

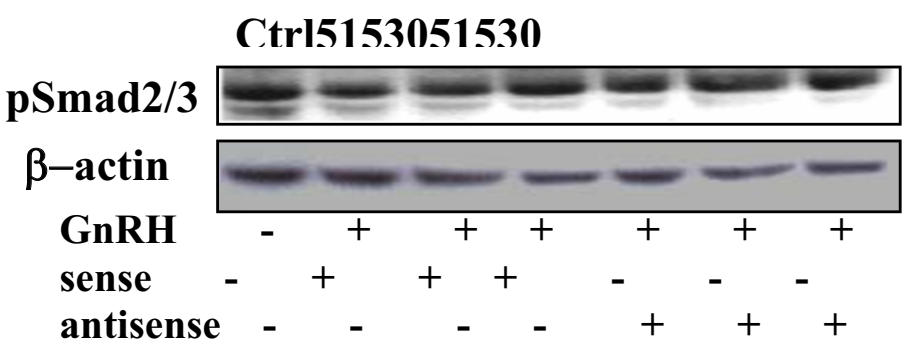

\section{ESC}

$\begin{array}{lllllllll}\mathbf{C} & \mathbf{t} & \mathbf{r} & \mathbf{l} & \mathbf{5} & \mathbf{1} & \mathbf{5} & \mathbf{3} & \mathbf{0}\end{array}$

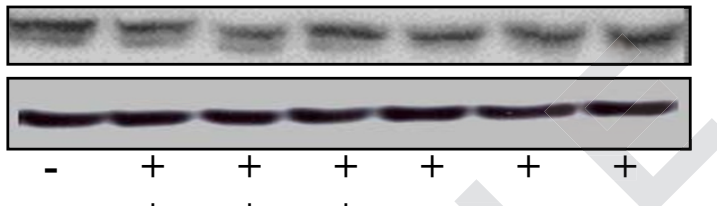

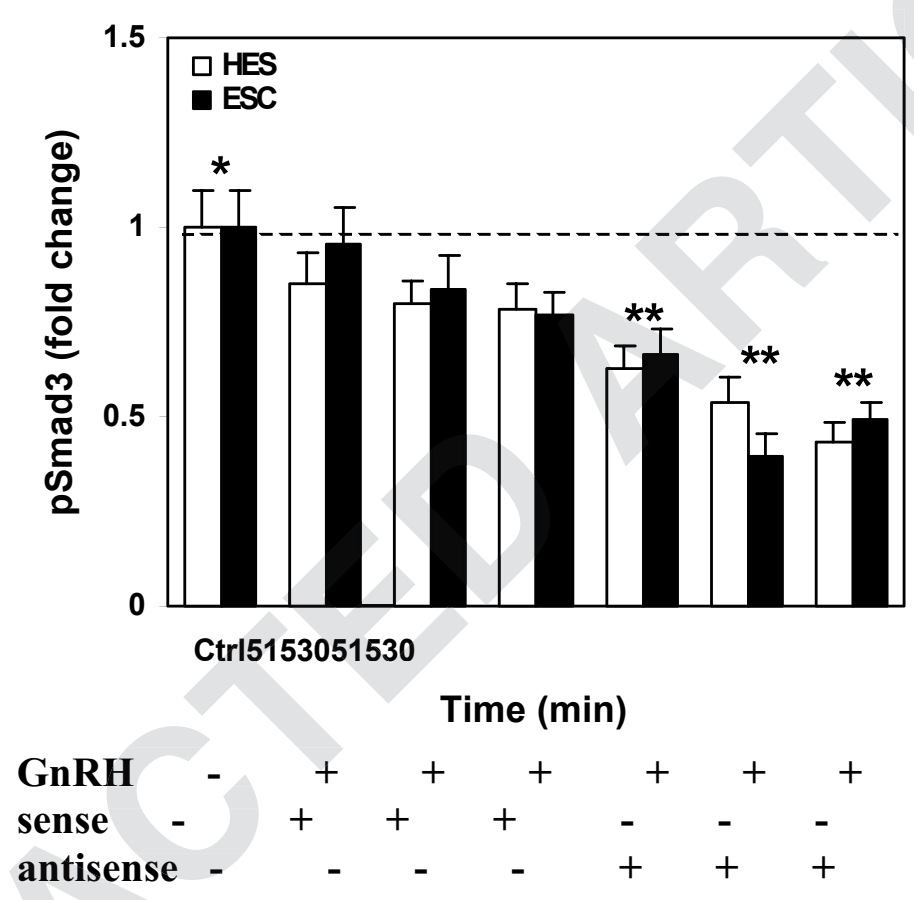

Figure 7

The effect of GnRH $(0.1 \mu M)$ on Smad3 activation in HES and ESC pretreated with TGF- $\beta$ type II receptor antisense (I $\mu$ M) or sense $(I \mu M)$ oligonucleotides for $24 \mathrm{hrs}$. The cell lysates were prepared from GnRH-treated $(+)$ and untreated $(-)$ cells after 5 , 15 and $30 \mathrm{~min}$ and analyzed by immunoblotting for $\mathrm{pSmad} 2 / 3$ and $\beta$-actin as loading control, shown from a representative experiment. Bar graph shows the mean \pm SEM of fold change in the rate of Smad3 activation from three independent experiments with denotes $* *$ are significantly different from untreated $(*)$ controls $(p<0.05)$.

Because endometrial epithelial and stromal cells express GnRH and TGF- $\beta$ receptors, GnRH-induced alteration of Smad expression could influence the outcome of TGF- $\beta$ autocrine/paracrine actions in the endometrium. Smad3 is phosphorylated by activated TGF- $\beta$ receptor type I and following complex formation with Smad4, translocate into the nucleus where they regulate transcriptional activation of target genes in response to TGF- $\beta$. The inhibitory
Smad7 also interacts with TGF- $\beta$ type I receptor, but prevents RSmads activation [33]. In the presents study we also found that GnRH altered the activation of Smad3 in ESC and HES. These observations provide the first example of interactions between GnRH and TGF- $\beta$ signaling in the endometrium, however, recent reports have also demonstrated a functional interaction between GnRH, TGF- $\beta$ and activin, involving Smad and MAPK activation in the 
pituitary gonadotropes, resulting in regulation of GnRH and GnRH receptor expression [35-38]. Collectively, these results support a potential crosstalk between GnRH and TGF- $\beta$ receptors signaling, involving Smad pathway in the endometrium and possibly the pituitary-gonadal axis. However, translocation of activated Smad3 into the nucleus is required for transcriptional activation of target genes. Unlike TGF- $\beta$ which induced nuclear accumulation on Smad3 in HES and ESC [34], GnRH treatment resulted in Smad3 accumulation around their nuclear peripheries. The biological significance of GnRH action on Smad3 cellular distribution around the nuclear periphery is unknown, however, activated Smad3 complexes with Smad4 prior to translocation into the nucleus. Therefore, alteration in Smad3 cellular distribution may represent an additional mechanism by which GnRH influences cellular response to TGF- $\beta$ autocrine/paracrine actions.

Our results also indicated that Antide (GnRH antagonist) had an inhibitory effect on Smad3 activation in ESC and HES, and found that TGF- $\beta$ autocrine/paracrine action may, in part, account for Smad3 activation in these cells. Until recently it was considered that the biological action of GnRH is mediated only through GnRH-I receptor. Identification of a second form of GnRH receptor, which is structurally and functionally distinct from GnRH-I receptor, suggests that GnRH action could be mediated through either or both receptors, with GnRH-I antagonists having agonistic effects on GnRH-II receptor [41-43]. Human endometrium expresses both forms of GnRH receptors, however it remains to be determined whether GnRH and Antide interact with one or both GnRH receptors, or Antide could convert an antagonist action into an agonist as seen in other cell types [51,52]. Both GnRH receptors are reported to mediate antiproliferative and apoptotic effects of GnRH [13,53].

In addition to modulating Smad3 activation, GnRH also altered the expression of Smad7 in HES and ESC. Smad7 is a key regulator of TGF- $\beta$ receptor mediated signaling whose expression is highly regulated by TGF- $\beta$ [44-46]. TGF- $\beta$ also regulates the expression of TGF- $\beta$ receptors, ECM, adhesion molecules, proteases, and proteases inhibitors [44-46], whose expression is documented in human endometrium and influenced by GnRHa therapy $[14,15,17,25]$. These molecules are key components of tissue remodeling process which is critical to endometrial tissue integrity during the menstrual cycle. Therefore, GnRH either directly, or through alteration of TGF- $\beta$ receptor mediated signaling, could target endometrial tissue remodeling in patients undergoing GnRHa therapy for medical management of endometriosis and leiomyoma, or controlled ovarian stimulation [4-8]. A recent study reported that during controlled ovarian stimulation, GnRHa induced an imbalance in endometrial expression of ovarian steroid receptors with a profound antimitotic effect as compared to endometrium of the natural cycle [8], resulting in an unfavorable environment for embryo implantation [4-8].

How GnRH receptor-mediated actions lead to alteration of Smads expression and activation of Smad3 remains to be elucidated. However, interaction and crosstalk with components of other signaling pathways such as PKC, MAPK and calcium/calmodulin $\left(\mathrm{Ca}^{2+} / \mathrm{CaM}\right)$, that are activated by GnRH and TGF- $\beta$ receptors can influence Smad pathway $[33,47,54-60]$. For instance, Smad3 has been shown to serve as a substrate for ERK2 $[57,61]$, while $\mathrm{Ca}^{2+} / \mathrm{CaM}$ alter receptor activated Smad functions [59]. Since co-treatment of HES and ESC with GnRH antagonized TGF- $\beta$ action on Smad3 activation, it is quite possible that a crosstalk between GnRH and TGF- $\beta$ receptor system is operational in HES and ESC. Such interaction between GnRH receptors signaling and crosstalk with Smad was demonstrated in the experiment using TGF- $\beta$ receptor antisense which blocked/reduced TGF- $\beta$ autocrine/paracrine action.

In conclusion, the results provide further evidence for the direct action of GnRH in human endometrium. Specifically, we demonstrated that GnRH alters the expression and activation of Smads in endometrial epithelial and stromal cells, suggesting a functional interaction between GnRH and TGF- $\beta$ receptor signaling pathways, a mechanism that could alter the endometrial response to TGF- $\beta$. TGF- $\beta$ is known to promote cell growth and differentiation, migration, invasion, angiogenesis, and extracellular matrix turnover, processes that influence the outcome of embryo implantation, endometriosis implants, endometriosis-associated adhesions and endometrial cancer.

\section{Acknowledgment}

Presented in part at the 49th Annual Meeting of the Society for Gynecological Investigation, Los Angeles CA, March 2002. Supported in part by a grant HD37432 from the National Institute of Health

\section{References}

I. Takeuchi H, Kobori H, Kikuchi I, Sato Y, Mitsuhashi N: A prospective randomized study comparing endocrinological and clinical effects of two types of GnRH agonists in cases of uterine leiomyomas or endometriosis. J Obstet Gynaecol Res 2000, 26:325-33I.

2. Grimbizis G, Tsalikis T, Tzioufa V, Kasapis M, Mantalenakis S: Regression of endometrial hyperplasia after treatment with the gonadotrophin-releasing hormone analogue triptorelin: a prospective study. Hum Reprod 1999, 14:479-484.

3. Burton JL, Wells M: Recent advances in the histopathology and molecular pathology of carcinoma of the endometrium. Histopathology 1998, 33:297-303.

4. Devroey P, Pados G: Preparation of endometrium for egg donation. Hum Reprod Update 1998, 4:856-86I.

5. Hernandez ER: Embryo implantation and GnRH antagonists: embryo implantation: the Rubicon for GnRH antagonists. Hum Reprod 2000, 15:1211-1216. 
6. Kol S: Embryo implantation and GnRH antagonists: GnRH antagonists in ART: lower embryo implantation? Hum Reprod 2000, I 5: I88I-I882.

7. Olivennes F, Cunha-Filho JS, Fanchin R, Bouchard P, Frydman R: The use of GnRH antagonists in ovarian stimulation. Hum Reprod Update 2000, 8:279-290.

8. Bourgain C, Ubaldi F, Tavaniotou A, Smitz J, Van Steirteghem AC, Devroey P: Endometrial hormone receptors and proliferation index in the periovulatory phase of stimulated embryo transfer cycles in comparison with natural cycles and relation to clinical pregnancy outcome. Fertil Steril 2002, 78:237-244.

9. Chegini N, Rong H, Dou Q, Kipersztok S, Williams RS: Gonadotropin releasing hormone (GnRH) and GnRH receptor gene expression in human myometrial and leiomyomta and the direct action of GnRH analogs on myometrial smooth muscle cells interaction with ovarian steroids in vitro. J Clin Endocrinol Metab 1996, 81:3215-3221.

10. Raga F, Casan EM, Kruessel JS, Wen Y, Huang HY, Nezhat C, Polan ML: Quantitative gonadotropin-releasing hormone gene expression and immunohistochemical localization in human endometrium throughout the menstrual cycle. Biol Reprod 1998, 59:661-669.

II. Dong KW, Marcelin K, Hsu MI, Chiang CM, Hoffman G, Roberts JL: Expression of gonadotropin-releasing hormone (GnRH) gene in human uterine endometrial tissue. Mol Hum Reprod 1998, 4:893-898.

12. Cheon KW, Lee HS, Parhar IS, Kang IS: Expression of the second isoform of gonadotrophin-releasing hormone (GnRH-II) in human endometrium throughout the menstrual cycle. Mol Hum Reprod 200I, 7:447-452.

13. Grundker C, Gunthert AR, Millar RP, Emons G: Expression of gonadotropin-releasing hormone II (GnRH-II) receptor in human endometrial and ovarian cancer cells and effects of GnRH-II on tumor cell proliferation. J Clin Endocrinol Metab 2002, 87:1427-1430.

14. Dou Q, Zhao Y, Tarnuzzer RW, Rong H, Williams RS, Schultz GS, Chegini N: Suppression of TGF- $\beta$ s and TGF- $\beta$ receptors mRNA and protein expression in leiomyomata in women receiving gonadotropin releasing hormone agonist therapy. J Clin Endocrinol Metab 1996, 81:3222-3230.

15. Dou Q, Tarnuzzer RW, Williams RS, Schultz GS, Chegini N: Differential expression of matrix metalloproteinases and their tissue inhibitors in leiomyomata: a mechanism for gonadotrophin releasing hormone agonist-induced tumour regression. Mol Hum Reprod 1997, 3:1005-1014.

16. Vignali M: Molecular action of $\mathbf{G n R H}$ analogues on ectopic endometrial cells. Gynecol Obstet Invest 1998, 45(Suppl I):2-5.

17. Raga F, Casan EM, Wen Y, Huang HY, Bonilla-Musoles F, Polan ML: Independent regulation of matrix metalloproteinase-9, tissue inhibitor of metalloproteinase-I (TIMP-I), and TIMP-3 in human endometrial stromal cells by gonadotropin-releasing hormone: implications in early human implantation. J Clin Endocrinol Metab 1999, 84:636-642.

18. Imai A, Takagi A, Tamaya T: Gonadotropin-releasing hormone analog repairs reduced endometrial cell apoptosis in endometriosis in vitro. Am / Obstet Gynecol 2000, 182: | | 42-1| 46.

19. Grundker C, Schlotawa L, Viereck V, Emons G: a Protein kinase Cindependent stimulation of activator protein-I and c-Jun $N$ terminal kinase activity in human endometrial cancer cells by the LHRH agonist triptorelin. Eur J Endocrinol 200I, 145:651-658.

20. Grundker C, Volker P, Emons G: Antiproliferative signaling of luteinizing hormone-releasing hormone in human endometrial and ovarian cancer cells through G protein $\alpha$ (I)-mediated activation of phosphotyrosine phosphatase. Endocrinology 200I, I 42:2369-2380.

21. Chegini N, Tang XM, Ma C, Williams RS: The effects of gonadotropin releasing hormone analogues, add-back, antiestrogen and antiprogestins on leiomyoma and myometrial smooth muscle cells growth and transforming growth factor beta expression. Mol Hum Reprod 2002, I 2: 107 I- 1078.

22. Tang XM, Zhao Y, Rossi MJ, Abu-Rustum RS, Ksander GA, Chegini N: Expression of transforming growth factor-beta (TGF $\beta$ ) isoforms and TGF $\beta$ type II receptor messenger ribonucleic acid and protein, and the effect of TGF $\beta$ s on endometrial stro- mal cell growth and protein degradation in vitro. Endocrinology 1994, 35:450-459.

23. Casslen B, Sandberg T, Gustavsson B, Willen R, Nilbert M: Transforming growth factor betal in the human endometrium. Cyclic variation, increased expression by estradiol and progesterone, and regulation of plasminogen activators and plasminogen activator inhibitor-I. Biol Reprod 1998, 58: $1343-1350$.

24. Sandberg T, Casslen B, Gustavsson B, Benraad T]: Human endothelial cell migration is stimulated by urokinase plasminogen activator:plasminogen activator inhibitor I complex released from endometrial stromal cells stimulated with transforming growth factor betal; possible mechanism for paracrine stimulation of endometrial angiogenesis. Biol Reprod 1998, 59:759-767.

25. Ma C, Chegini N: Regulation of matrix metalloproteinases (MMPs) and their tissue inhibitors in human myometrial smooth muscle cells by TGF- $\beta$ I. Mol Hum Reprod 1999, 10:950-954

26. Chegini N, Williams RS: Implication of growth factor and cytokine networks in endometrium. In Cytokines in human reproduction Edited by: Hill J. Wiley \& Sons Publisher. New York; 2000:92-132.

27. Blobe GC, Schiemann WP, Lodish HF: Role of transforming growth factor beta in human disease. N Engl J Med 2000 , 342:1350-1358.

28. Chegini N, Gold LI, Williams RS: Localization of transforming growth factor beta isoforms TGF- $\beta$ I, TGF- $\beta 2$, and TGF- $\beta 3$ in surgically induced endometriosis in the rat. Obstet Gynecol 1994, 83:455-46I.

29. Oosterlynck DJ, Meuleman C, Waer M, Koninckx PR: Transforming growth factor-beta activity is increased in peritoneal fluid from women with endometriosis. Obstet Gynecol 1994, 83:287-292.

30. Gold LI, Saxena B, Mittal KR, Marmor M, Goswami S, Nactigal L, Korc $M$, Demopoulos RI: Increased expression of transforming growth factor beta isoforms and basic fibroblast growth factor in complex hyperplasia and adenocarcinoma of the endometrium: evidence for paracrine and autocrine action. Cancer Res 1994, 54:2347-2358.

3I. Bruner KL, Rodgers WH, Gold LI, Korc M, Hargrove JT, Matrisian LM, Osteen KG: Transforming growth factor beta mediates the progesterone suppression of an epithelial metalloproteinase by adjacent stroma in the human endometrium. Proc Natl Acad Sci USA 1995, 92:7362-7366.

32. Lea RG, Underwood J, Flanders KC, Hirte H, Banwatt D, Finotto $S$, Ohno I, Daya S, Harley C, Michel M: A subset of patients with recurrent spontaneous abortion is deficient in transforming growth factor beta-2-producing "suppressor cells" in uterine tissue near the placental attachment site. Am J Reprod Immunol 1995, 34:52-64.

33. Dennler S, Goumans MJ, ten Dijke P: Transforming growth factor beta signal transduction. J Leukoc Biol 2002, 7 I:73।-740.

34. Luo X, Xu J, Chegini N: The expression of Smads in human endometrium and regulation and induction in endometrial epithelial and stromal cells by transforming growth factorbeta. J Clin Endocrinol Metab 2003, 88:4967-4976.

35. Yamada Y, Yamamoto H, Yonehara T, Kanasaki H, Nakanishi H, Miyamoto E, Miyazaki K: Differential activation of the luteinizing hormone \{beta\}-subunit promoter by activin and gonadotropin-releasing hormone: A role for the mitogen-activated protein kinase signaling pathway in L\{beta\} T2 gonadotrophs. Biol Reprod 2003. [Epub ahead of print]

36. Ellsworth BS, Burns AT, Escudero KW, Duval DL, Nelson SE, Clay $\mathrm{CM}$ : The gonadotropin releasing hormone $(\mathrm{GnRH})$ receptor activating sequence (GRAS) is a composite regulatory element that interacts with multiple classes of transcription factors including Smads, AP-I and a forkhead DNA binding protein. Mol Cell Endocrinol 2003, 206:93-III.

37. Norwitz ER, Xu S, Xu J, Spiryda LB, Park JS, Jeong KH, McGee EA, Kaiser UB: Direct binding of AP-I (Fos/Jun) proteins to a SMAD binding element facilitates both gonadotropin-releasing hormone (GnRH)- and activin-mediated transcriptional activation of the mouse GnRH receptor gene. J Biol Chem 2002, 277:37469-37478. 
38. Norwitz ER, Xu S, Jeong KH, Bedecarrats GY, Winebrenner LD, Chin WW, Kaiser UB: Activin A augments GnRH-mediated transcriptional activation of the mouse GnRH receptor gene. Endocrinology 2002, I 43:985-997.

39. Xu J, Luo $X$, Chegini N: Differential expression, regulation, and induction of Smads, transforming growth factor-beta signal transduction pathway in leiomyoma, and myometrial smooth muscle cells and alteration by gonadotropin-releasing hormone analog. J Clin Endocrinol Metab 2003, 88: 1350-I36I.

40. Chegini N, Rossi MJ, Masterson BJ: Platelet-derived growth factor (PDGF), epidermal growth factor (EGF), and EGF and PDGF beta-receptors in human endometrial tissue: localization and in vitro action. Endocrinology 1992, 130:2373-2385.

4I. Kraus S, Naor Z, Seger R: Intracellular signaling pathways mediated by the gonadotropin-releasing hormone (GnRH) receptor. Arch Med Res 200I, 32:499-509.

42. Leung PC, Cheng CK, Zhu XM: Multi-factorial role of GnRH-I and GnRH-II in the human ovary. Mol Cell Endocrinol 2003, 202: I 145-I53.

43. Millar RP: GnRH II and type II GnRH receptors. Trends Endocrinol Metab 2002, I 4:35-43.

44. Afrakhte M, Moren A, Jossan S, Itoh S, Sampath K, Westermark B, Heldin $\mathrm{CH}$, Heldin NE, ten Dijke P: Induction of inhibitory Smad6 and Smad7 mRNA by TGF-beta family members. Biochem Biophys Res Commun 1998, 249:505-5II.

45. Massague J, Wotton D: Transcriptional control by the TGF- $\beta$ I Smad signaling system. EMBO J 2000, 19:1745-1754.

46. Stopa M, Anhuf D, Terstegen L, Gatsios P, Gressner AM, Dooley S: Participation of Smad2, Smad3, and Smad4 in transforming growth factor beta (TGF- $\beta$ )-induced activation of Smad7. The TGF- $\beta$ response element of the promoter requires functional Smad binding element and E-box sequences for transcriptional regulation. J Biol Chem 2000, 275:29308-293I7.

47. Garcia-Montero AC, Vasseur S, Giono LE, Canepa E, Moreno S, Dagorn JC, lovanna JL: Transforming growth factor beta-I enhances Smad transcriptional activity through activation of p38 gene expression. Biochem J 200I, 357:249-253.

48. Pouliot F, Labrie C: Expression profile of agonistic Smads in human breast cancer cells: absence of regulation by estrogens. Int J Cancer 1999, 81:98-103.

49. Brodin G, ten Dijke P, Funa K, Heldin CH, Landstrom M: Increased smad expression and activation are associated with apoptosis in normal and malignant prostate after castration. Cancer Res 1999, 59:2731-2738.

50. Matsuda T, Yamamoto T, Muraguchi A, Saatcioglu F: Cross-talk between transforming growth factor-beta and estrogen receptor signaling through Smad3. I Biol Chem 200I, 276:42908-429/4.

5I. Ott TR, Troskie BE, Roeske RW, Illing N, Flanagan CA, Millar RP: Two mutations in extracellular loop 2 of the human GnRH receptor convert an antagonist to an agonist. Mol Endocrinol 2002, 16:1079-1088.

52. Sun YM, Flanagan CA, Illing N, Ott TR, Sellar R, Fromme B, Hapgood J, Sharp P, Sealfon SC, Millar RP: A chicken gonadotropin-releasing hormone receptor that confers agonist activity to mammalian antagonists. Identification of D-Lys(6) in the ligand and extracellular loop two of the receptor as determinants. J Biol Chem 200I, 276:7754-776I.

53. Everest HM, Hislop JN, Harding T, Uney JB, Flynn A, Millar RP, McArdle CA: Signaling and antiproliferative effects mediated by GnRH receptors after expression in breast cancer cells using recombinant adenovirus. Endocrinology 200I, I 42:4663-4672.

54. Schiffer M, Bitzer M, Roberts IS, Kopp JB, ten Dijke P, Mundel P, Bottinger EP: Apoptosis in podocytes induced by TGF- $\beta$ and Smad7. J Clin Invest 200I, 108:807-816.

55. Landstrom M, Heldin NE, Bu S, Hermansson A, Itoh S, ten Dijke P, Heldin $\mathrm{CH}$ : Smad7 mediates apoptosis induced by transforming growth factor beta in prostatic carcinoma cells. Curr Biol 2000, 1 0:535-538.

56. Chegini N, Kornberg L: Gonadotropin releasing hormone analogue (GnRHa) therapy alters signal transduction pathways involving MAP and focal adhesion kinases in leiomyoma. J Soc Gynecol Investig 2003, 1 0:21-26.

57. Yue J, Mulder KM: Requirement of Ras/MAPK pathway activation by transforming growth factor beta for transforming growth factor beta I production in a Smad-dependent pathway. J Biol Chem 2000, 275:30765-30773.

58. Zimmerman CM, Padgett RW: Transforming growth factor beta signaling mediators and modulators. Gene 2000, 249: 17-30.

59. Scherer A, Graff JM: Calmodulin differentially modulates SmadI and Smad2 signaling. J Biol Chem 2000, 275:4| 430-4I 438.

60. Yakymovych I, Ten Dijke P, Heldin CH, Souchelnytskyi S: Regulation of Smad signaling by protein kinase C. FASEB J 200I, I 5:553-555.

61. Kretzschmar M, Doody J, Timokhina I, Massagué J: A mechanism of repression of TGFb/Smad signaling by oncogenic Ras. Genes Dev 1999, |3:804-8|6.

Publish with Bio Med Central and every scientist can read your work free of charge

"BioMed Central will be the most significant development for disseminating the results of biomedical research in our lifetime. "

Sir Paul Nurse, Cancer Research UK

Your research papers will be:

- available free of charge to the entire biomedical community

- peer reviewed and published immediately upon acceptance

- cited in PubMed and archived on PubMed Central

- yours - you keep the copyright
BioMedcentral 